\title{
Orman içi ve kenarı yerleşimlerde orman yangınları tehlike oranlaması modeli: Antalya Orman Bölge Müdürlüğü örneği
}

A wildfire hazard rating model for residential structures within and around the forest areas: The case of Antalya Forestry Regional Directorate

Ersin YILMAZ ${ }^{1}$

Arif KAYACAN ${ }^{1}$

Kader Hale GÜLER ${ }^{1}$

'Batı Akdeniz Ormancılık Araştırma Enstitüsü Müdürlüğ̈̈, Antalya

Sorumlu yazar (Corresponding author) Ersin YILMAZ

eyilmaz33@gmail.com

Geliş tarihi (Received)

21.05.2018

Kabul Tarihi (Accepted)

05.06.2018

Atuf (To cite this article): YILMAZ, E, KAYACAN, A, GÜLER, K . (2019). Orman içi ve kenarı yerleşimlerde orman yangınları tehlike oranlaması modeli: Antalya Orman Bölge Müdürlüğü örneği. Ormancılık Araştırma Dergisi, 6 (1), 1-14. DOI: $10.17568 /$ ogmoad. 425476

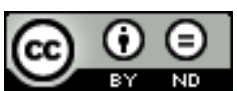

Creative Commons Atıf Türetilemez 4.0 Uluslararas Lisansı ile lisanslanmıştır.

\section{$\ddot{O} z$}

Yangında can ve mal kaybının azaltılması açısından orman yangını s1rasında yapıların yanma riskinin değerlendirilmesi, yani "orman yangınları tehlike oranlaması" çalışmaları büyük önem arz etmektedir. Bu araştırmada Analitik Hiyerarşi Süreci (AHS) tekniği kapsamındaki "ikili karşılaştırmalar" yaklaşımı yardımı ile orman yangınları yönetimi konusundaki uzmanların hükümleri ortaya konulmuş ve orman yangınları tehlike ana kriterlerinin ve alt kriterlerinin ağırlıkları bu uzman hükümlerine dayalı olarak belirlenmiştir. Daha sonra ana kriterlerin ve alt kriterlerin kombine edilmesinde "Doğrusal Kombinasyon" tekniği isimli çok kriterli çözümlemeden faydalanılmıştır. "Yüksek yangın tehlike oranına" sahip bina tipleri arasında "Orman İçi Köyde Bulunan Bina 4" 2,313 toplam yangın tehlike puanı ile en yüksek yangın tehlike oranına sahip bina tipi olarak belirlenmiştir. "Orta yangın tehlike oranına" bina tipleri arasında "Tatil Köyü 2" 1,895 toplam yangın tehlike puanı ile en yüksek yangın tehlike oranına sahip bina tipi olarak saptanmıştır. Buna karşın yapılan yangın tehlike oranlaması çözümlemelerinde "düşük yangın tehlike oranına" sahip bina tipi ortaya çıkmamıştır.

Anahtar Kelimeler: Orman yangınları yönetimi, orman içi ve kenarı yerleşimler, orman yangınları tehlike oranlaması modeli, analitik hiyerarşi süreci, doğrusal kombinasyon tekniği, Antalya ili

\section{Abstract}

It is important to evaluate structure ignition risk during a wildland fire, i.e. wildfire hazard rating studies. At this study, "Linear Combination" approach in Analytic Hierarchy Process (AHP) technique, which is a method based on mathematical combination, was adopted for wildfire hazard rating method. First, it would establish a set of weights for each of the primary criteria and sub-criteria. It was found that the "pairwise comparison" approach in AHP technique was very useful for this aim. So different wildland fire experts' judgments would be specified by using this approach, and the weights of the primary criteria and sub-criteria were evaluated with respect to judgments made by different wildland fire experts. Later on, multiple criteria analysis, i.e. Linear Combination technique, was used to combine the primary criteria and sub-criteria. Building type 4 that had 2,313 total fire hazard points was building type that had the highest fire hazard ratio among building types that had "high fire hazard ratio". Holiday village 2 that had 1,895 total fire hazard points was building type that had the highest fire hazard ratio among building types that had "middle fire hazard ratio". There was no building type that had "low fire hazard ratio".

Keywords: Wildfire management, residential structures within and around the forest areas, wildfire hazard rating model, analytic hierarchy process, linear combination technique, Antalya province. 


\section{Giriş}

Orman yangınları büyük alanları etkilemekte ve ekolojik, sosyal ve ekonomik zararlara neden olmaktadır. Güney Avrupa ülkelerinde her yil 50.000 'den fazla orman yangını, yaklaşık 500.000 ha vejetasyonu etkilemektedir (Lampin-Maillet, 2008). "Orman-Yerleşim Arayüzü (OYA)" alanlar1, orman yangınlarıyla doğrudan ilgilidir. Zira ülkemizin de dâhil olduğu Akdeniz Avrupa'sında orman yangınlarının yaklaşık \%90'1, insan faaliyetleri sonucu ortaya çıkmakta (Eufirelab, 2004) ve her yıl OYA alanlarında yaşayan birkaç insan orman yangınları ile hayatını kaybetmektedir. Yüksek kentsel baskı ve orman biyomasının birikimi sonucu, orman yangını yönetimi açısından ciddi sorunlar ortaya çıkmaktadır. Özellikle ülkemizin güney ve batı bölgelerinde ormanla iç içe olan kentleşmeler, bu çalışmada OYA olarak adlandırılan yeni mekânsal yapılar ortaya koymaktadır. OYA alanları, vejetasyon ile kentsel sistemler arasındaki teması açıklamaktadır. Bu arayüzlerin gelecek yıllarda ülkemizde daha da genişleyeceği tahmin edilebilir.

Tarihsel olarak ülkemizde orman yangınları öncesi bir yönetim veya orman yangınları tehlikesini azaltma faaliyetlerinden ziyade, çıkan orman yangınlarının söndürülmesine odaklanılmış bir orman yangınları yönetim politikası hâkimdir. Bugünkü orman yangınları tehlikesi sorununun altında yatan ana faktörlerden birisi, tarihten bu yana gelen orman yangınları söndürmesine dayalı bu politikadır. Zira orman yangınlarının çoğu ekosistemin doğal bir parçası olmasından dolayı, tamamıyla orman yangınlarının söndürülmesine dayalı bir yönetim anlayışı, ormanda mevcut yanıcı maddenin doğal olmayan bir şekilde birikmesi anlamına gelmektedir. Bu durum yangın rejimlerinde bir değişikliğe neden olmakta, alanları çoğunlukla yangına daha hassas olan rejimlere dönüştürmekte ve böylece büyük orman yangınlarının sayısını arttırmaktadır (McCaffrey, 2002; Neyişçi, 2009; Yılmaz ve ark., 2012).

$\mathrm{Bu}$ politikanın da etkisiyle ormanlık ve makilik alanlar içerisindeki ve kenarındaki yerleşimlerde (orman içi ve kenarında köyler, villalar, tatil siteleri, pansiyonlar, turistik oteller, apart daireler, yayla yerleşimleri vb.) yer alan binalar da, yoğun miktarda yanıcı madde içeren ortamlarda bulunmaktadır. $\mathrm{Bu}$ binalar ve tesisler (bundan böyle sadece bina olarak anılacaktır), hem kendi inşaatında kullanılan yanıcı maddelerin hem de çevresindeki orman vejetasyonuna ait yanıcı maddelerin ortak etkisiyle önemli bir orman yangınları yönetim sorunu oluşturmaktadır.
$\mathrm{Bu}$ ormanlık ve makilik alanlar içerisindeki ve kenarındaki yerleşimler, orman yangınları mevsiminde Orman Teşkilatı için ek bir yük oluşturmaktadır. Zira bu alanlarda yaşanacak bir orman yangınında, binaların söndürülmesinde yasal sorumluluğun kimde olduğunun bilinmemesi nedeniyle (Küçükaydın, 2009), Orman Teşkilatının yangınla mücadele kaynaklarının bir bölümünü ve hatta bazen tamamını orman yangını söndürme faaliyetinin yerine bu alanlardaki binaları korumaya ayırması gerekecektir (Gençol, 2009). Bu durum ise çoğunlukla orman yangını söndürme süresini uzatacak, orman kaynakları üzerinde daha fazla zarara neden olacak ve böylece orman yangını söndürme maliyetini arttıracaktır. Sonuçta ormancılık sektörünün kıt kaynaklarının yerleşim yerlerindeki binaların korunmasına tahsis edilmesi, orman yangınlarının toplam zararı üzerine önemli bir etkiye sahip olacaktır.

Bunun için öncelikle yangında can ve mal kaybının azaltılması açısından, orman yangını sırasında yapıların yanma riskinin değerlendirilmesi, yani orman yangınları tehlike oranlaması çalışmaları büyük önem arz etmektedir. Ülkemizde orman içi ve kenar1 yerleşimlerdeki binalara yönelik orman yangınları tehlike oranlaması konusundaki bilgi boşluğunun doldurulmasına katkı yapmak üzere, bu çalışmanın literatüre kazandırılması gerekmiştir.

$\mathrm{Bu}$ çalışmanın ana amacı; ülkemizin orman yangını tehlikesi taşıyan ormanlık ve makilik alanlar içerisindeki ve kenarındaki yerleşimlerde yer alan binalar (orman içi ve kenarında köy binaları, villalar, tatil köyleri, kamu kurum ve kuruluşları, okul, hastane, fabrika ve benzin istasyonu) için orman yangınları tehlikesinin belirlenmesi ve ölçülmesine yönelik uygulanabilir bir "orman yangınları tehlike oranlaması modeli” geliştirmektir. Diğer amacı binalarda ve bina çevrelerinde orman yanginları tehlike oranlaması üzerine etkisi olan en önemli kriterlerin belirlenmesini sağlayan bir orman yangınları tehlike bilgisi elde etme metodu geliştirmektir. Bir diğer amaç binalarda ve bina çevrelerinde orman yangınları tehlikesinin azaltılması için hangi eylemlerin etkili olduğunu belirlemek ve bu yerleşimlerdeki binalara yönelik orman yangınları tehlikesi konusunda ilgili kuruluşları (orman teşkilatı, yerel yönetimler, afet yönetimi, sağlık kuruluşları vb.) bilgilendirmektir. Diğer amaçlar ise binalarda orman yangınları tehlikesinin azaltılması yönünde bina sahiplerinin ve ilgili kuruluşların harekete geçmelerini temin etmek, yangın öncesi çalışmalara ve planlamalara destek sağlayacak bilgiler elde etmek, bina inşaatlarına başlanabilmesi için alınacak inşaat ruhsatlarında kullanılabilecek bir karar verme modeli geliştir- 
mek ve binaların yangın sigortası genel şartlarının belirlenmesine katkıda bulunmaktır.

\section{Materyal ve Yöntem}

\subsection{Materyal}

Çalışma, Antalya Orman Bölge Müdürlüğü çalışma alanında uygulanmıştır (Şekil 1).

Çalışmaya yönelik gerekli verilerin elde edilmesi için öncelikle bir "ön bilgi toplama formu” ve "ön anket formu“ hazırlanmıştır. Bu formlar, Batı Akdeniz Ormancılık Araştırma Enstitüsü Müdürlügünde görev yapan teknik elemanlara uygulanmıştır. Bu şekilde anket formlarının anlaşılabilirliği ve uygulanabilirliği sınanmak istenmiştir. Ayrıca Batı Akdeniz Ormancılık Araştırma Enstitüsü Müdürlüğü teknik elemanlarından alınan tavsiyelere göre formlar üzerinde gerekli ayarlamalar yapılmıştır. Sonuçta araştırmada kullanılacak nihai bilgi toplama formu ve nihai anket formu elde edilmiştir.

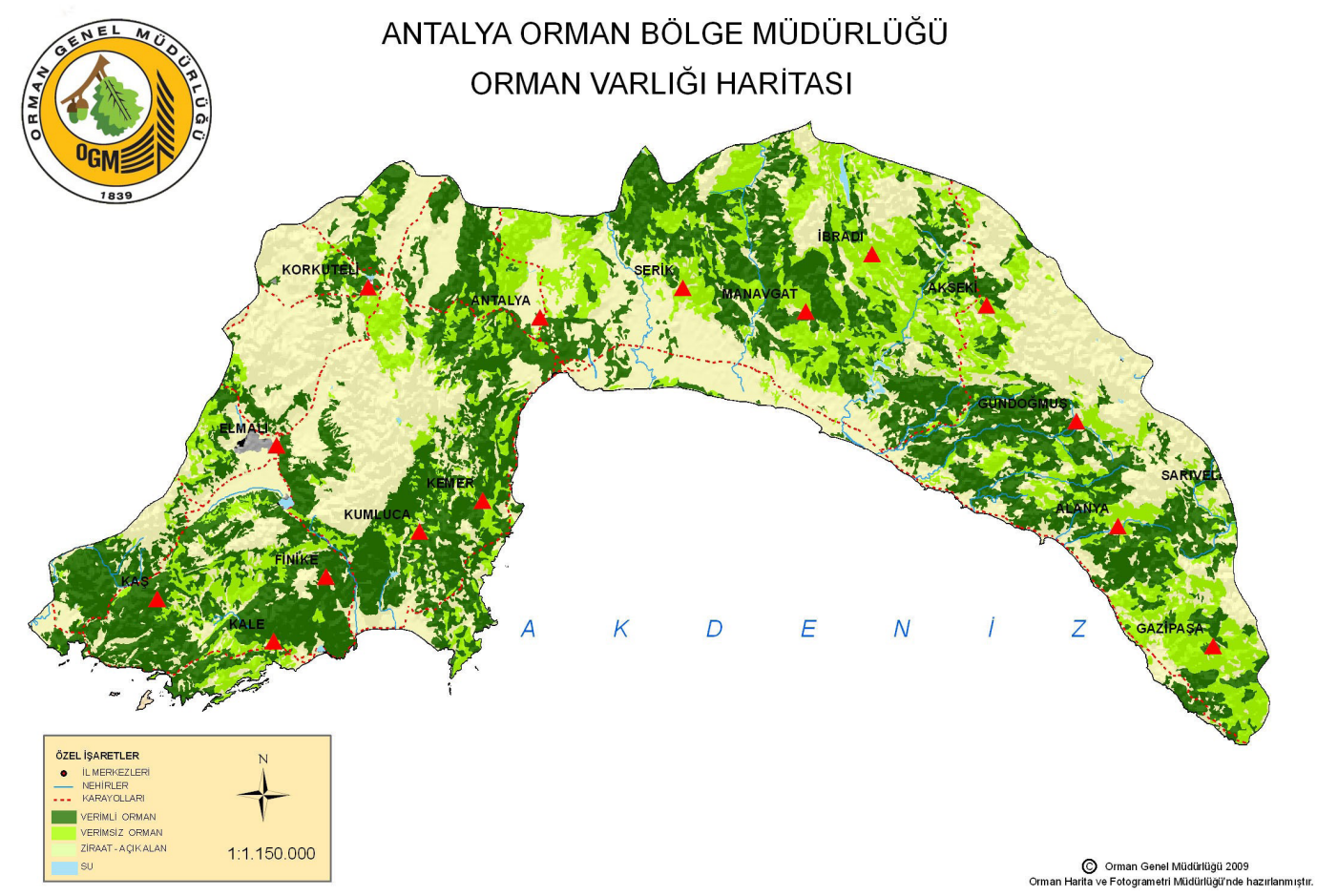

Şekil 1: Antalya Orman Bölge Müdürlüğü.

Figure 1: Antalya Forestry Regional Directorate.

Sonrasında araştırma alanında bilgi toplama formundaki her bir binanın ayrıntılı adres bilgileri ve bina sahibine ait iletişim bilgileri doldurulmuş, her bir kritere ve alt kritere ait bilgi toplama soruları cevaplanmış ve yorum sayfasına ilgili binaya ve çevresine yönelik yorumlar veya alan hakkındaki genel gözlemler kaydedilmiştir.

Ardından son şekli verilen orman yangınları tehlike kriterine ve alt kriterlerine yönelik kriter ve alt kriter ağırlıklarının belirlenmesine yönelik anket formları ise proje ekibince Antalya Orman Bölge Müdürlüklerinde görevli orman kaynakları yöneticilerine, Batı Akdeniz Ormancılık Araştırma Enstitüsü Müdürlüğü uzmanlarına ve Büyükşehir Belediyesi İtfaiye Dairesi yöneticilerine yüz yüze görüşme yoluyla doldurtulmuştur.

\subsection{Yöntem}

\subsubsection{Araştırmada geliştirilen orman yangınları} tehlike oranlaması

Belirli bir alan için yangın tehlikesini azaltma eylemlerinden hangilerinin daha çok etkili olduğunu belirlemek için, orman yangınları tehlike oranlamasını oluşturan kriterlerin en önemlilerini belirlemek gereklidir. Ülkemizde orman içi ve kenarı yerleşimlerdeki binalara yönelik orman yangınları tehlike oranlaması konusu henüz çalışılmamıştır. $\mathrm{Bu}$ araştırmada geliştirilecek ve uygulanacak modelleme çalışmasıyla, ülkemizdeki orman içi ve kenarı yerleşimler yer alan binalar için uygun bir orman yangınları tehlike oranlamasına yönelik sayısal bir sistem geliştirilmiştir. Böylece bu alanlardaki herhangi bir bina için kullanıcıların orman yangını tehlikesine katkıda bulunan en önemli 
kriterleri ve alt kriterleri belirlemeleri yönünde uygulanabilen bir orman yangını tehlike bilgisi toplama metodu ortaya konmuştur. Buna dayalı olarak araştırma alanındaki orman içi ve kenarı yerleşimlerdeki binalar için orman yangınları tehlikesini azaltmaya yönelik alınabilecek önlemler konusunda ayrıntılı bilgiler elde edilmiştir. Bu bilgiler ülkemizdeki bina sahipleri ve ilgili kuruluşların yangın tehlikesini azaltma eylemleri için yol gösterici olacaktır.

$\mathrm{Bu}$ araştırmada kullanılan orman yangınları tehlike oranlaması modelindeki orman yangınları tehlike ana kriterlerine ve alt kriterlerine ait ağırlık değerlerinin hesaplanmasında "Analitik Hiyerarşi Süreci (AHS)" tekniği kapsamındaki “ikili karş1laştırmalar" yaklaşımından yararlanılmıştır. Zira bu araştırmada uygulanmak üzere geliştirilen orman yangınları tehlike oranlamasına yönelik model, orman yangınları konusunda uzmanların yer aldığ 1 bir karar verme süreci olarak düşünülmüştür. Bu model yangın uzmanlarının orman yangınları tehlikesi bünyesindeki ana kriterlere ve alt kriterlere ait ağırlık değerlerini belirlemede aktif bir role sahip olmasını gerektirmektedir. Bu şekilde orman yangınları tehlike oranlamasına ilişkin kararlarda, yangın uzmanlarının farklı bakış açıları dikkate alınarak etkileşim ve işbirliğinin sağlanacağ1 düşünülmektedir. Böylece uzman görüşlerine dayalı orman yangınları tehlike oranlaması modeline ulaşılmıştır.

\subsubsection{Modelin kurulması ve problemin formüle edilmesi}

Bir OYA toplumunun orman yangınlarına karşı risklerin azaltılması ve risklerin değerlendirilmesine yönelik metotlar; ya orman yanıcı maddelerine ya da yerleşim yerlerinin yanıcı maddelerine odaklanarak gruplandırılabilir. Bunlardan ilk belirtilen orman yanıcı maddeleri, geleneksel olarak Orman Bakanlığı, Orman Genel Müdürlüğü, ilgili Orman Bölge Müdürlüğü ve dolayısıyla Orman İşletme Müdürlüğü ve Orman İşletme Şefliğinin sorumluluğunda iken, sonraki belirtilen yerleşim yerlerine ait yanıcı maddeler ise bina sahipleri ve İtfaiye Teşkilatı sorumluluğunda olması beklenir.

Öte yandan topoğrafya ve hava halleri (iklim) gibi diğer faktörlerin de önemli tehlike ve risk faktörleri olduğuna dikkat etmek gerekse de, bu faktörlerin hem orman yanıcı maddelerinde hem de yerleşim yeri yanıcı maddelerinde yangının yayılmasına eşit şekilde etkili olduğu söylenebilir.

\subsubsection{Kriterler}

$\mathrm{Bu}$ çalışmada kullanılan orman yangınları tehlike kriterleri ve alt kriterlerinin belirlenmesinde, bu konuda daha önceden yapılmış benzer çalışmalar (Johnson ve ark., 1993; Farmer, 1998; Hay, 2000; Slack, 2000; Tele ve Weatherford, 2000) yol gösterici olmuştur.

$\mathrm{Bu}$ çalışma için seçilen orman yangınları tehlike kriterlerinin sayısı (ikili karşılaştırmalara konu elemanlarının sayısı) $7 \pm 2$ kadar olmalıdır (Schmoldt ve ark., 1994). Bu nedenle AHS tekniği kapsamındaki ikili karşılaştırmaları sağlıklı şekilde yapabilmek için, orman yangınları tehlike kriterleri 7 kriter altında gruplandırılmıştır. Böylece çalışmada geliştirilen orman yangınları tehlike oranlaması modeli, çok kriterli çözümleme modellerine uygun şekilde, kriterlerin gruplandırılmasına dayandırılmıştır.

Orman yangınları tehlike oranlaması modeline ait seçilen 7 kriter aşağıdaki şekilde sıralanmıştır:

1. Topoğrafya kriteri,

2. Yanıcı maddeler kriteri,

3. Yapı inşa tarzı ve tasarımı kriteri,

4. Binanın yakın çevresindeki yanıcı maddeler kriteri,

5. Binaya ulaşılabilirlik kriteri,

6. Alandaki hizmetler ve yangına ilk müdahale zamanı kriteri,

7. Su mevcudiyeti kriteri.

\subsubsection{Alt Kriterler}

Yukarıda sıralanan her bir orman yangınları tehlike kriterleri altındaki orman yangınları tehlike alt kriterleri aşağıda açıklanmıştır:

Topoğrafya kriteri: $\mathrm{Bu}$ kriter, alanın fiziksel yapısından dolayı binanın karşı karşıya olduğu yangın tehlikesini ifade etmektedir. Fiziksel yapı kriterlerinin ilkini, alanın topoğrafik yapısı oluşturmaktadır. Topoğrafik yapı kriteri kapsamındaki orman yangınları tehlike alt kriterleri olarak aşağıdakiler seçilmiştir:

- Binanın eğim üzerindeki yeri,

- Binanın dik (\%30'dan daha büyük) bir eğimden olan uzaklığı,

- Binadan 50 metre uzaklık (yarıçap) içindeki alanda ortalama eğim,

- Binadan 50 metre uzaklık (yarıçap) içindeki alanın hâkim eğim yönüne ait bakı sınıfı,

- Binanın tehlikeli topoğrafik özelliklere (dik yamaç, yarık, oluk, kanyon, sırt, boyun vb.) 
olan uzaklı̆̆1,

- Binadan 150 metre uzaklıkta bulunan tehlikeli topoğrafik özellikler.

Yanıcı maddeler kriteri: Fiziksel yapı kriterlerinin ikinci grubunu ise alanın içinde ve çevresindeki yanıcı maddeler, yani vejetasyon tipi oluşturmaktadır. Yanıcı maddeler kapsamında yer alan orman yangınları tehlike alt kriterleri ise şunlar olmuştur:

- Bina çevresi ortam,

- Binadan 50 metre uzaklık (yarıçap) içindeki hâkim yanıcı madde tipi,

- Binadan en az 10 metre uzaklık (yarıçap) içindeki alanda vejetasyon yoğunluğu,

- Binadan en az 10 metre uzaklık (yarıçap) içindeki meşcerenin üst tabakası (ağaç türleri),

- Binadan en az 10 metre uzaklık (yarıçap) içindeki meşcerenin ara tabakası (çalılar, bodur ağaçlar, fundalıklar veya ağaçların budanmamış alt dalları),

- Binadan en az 10 metre uzaklık (yarıçap) içindeki meşcerenin alt tabakası (diri örtü veya toprak yüzeyi malzemesi).

Yapı İnşa Tarzı ve Tasarımı Kriteri: Bu kriter, bina inşaatında kullanılan malzemeler ve binanın inşa ediliş tarzına dayalı olarak bir binanın orman yangınına karşı içinde bulunduğu tehlikeyi göstermektedir. Bu kapsamda orman yangınları tehlike oranlaması modeline dâhil olan tehlike alt kriterleri şunlardır:

- Binanın çatı örtüsü malzemesi,

- Binanın çatı saçakları ve çıkıntılarının inşa ediliş tarzı,

- Bina bacasının yapıs1,

- Binanın duvar kaplama malzemesi,

- Bina balkonlarının inşa ediliş tarzı,

- Bina balkonlarının malzemesi,

- Binanın temeline yakın taban kısmının (bina eteği için kaplamanın) inşa ediliş tarzı,

- Bina pencerelerinin yangına dayanıklılığı.

Binanın Yakın Çevresindeki Yanıcı Maddeler Kriteri: Bu kriter, binanın hemen çevresinde depolanan yakacak odun, bina çatısındaki veya çatı oluklarındaki dal, yaprak, çerçöp vb. ve bina bacasina veya soba borusuna yakın vejetasyon nedeniyle, bir binanın orman yangınlarına yönelik sahip olduğu tehlikeyi temsil etmektedir. Bu konu kapsamında orman yangınları tehlike değerlendirmelerinde dikkate alınan alt kriterler aşağıdadır:

- Yakacak odun depolama yerinin binadan uzaklığ 1 ,

- Çalı-çırpı yığılan yerin binadan uzaklığı,

- Akaryakıt deposunun binadan uzaklığı,

- Çöp yakma varilinin binadan uzaklığı,

- Toprak altında veya toprak üstünde dökme gaz (LPG) tankının binadan uzaklığı,

- Kulübe, baraka vb. ek yapının binadan uzak$\operatorname{lig} 1$,

- Bina çatısındaki veya yakınındaki yanıcı maddeler (dal, vejetasyon vb.),

- Bina çatısının temizliği (yaprak, çerçöp vb.),

- Vejetasyonun bina bacasina veya soba borusuna yakınlı̆̆ 1 ,

- Binanın komşu binadan olan uzaklığı.

Binaya Ulaşılabilirlik Kriteri: Bu kriter, bir yangın durumunda yangın çalışanlarının ve teçhizatının binaya ulaşmadaki kolaylığı ile ilgilidir. $\mathrm{Bu}$ kapsamda değerlendirilen kriterlere; yol genişliği ve eğimi, özel araç yolunun özellikleri (kullanıma elverişliliği ve ana yol ağına bağlandığı yer), elektrik hatları ve bina tanıtım levhası dâhildir. Tüm bu kriterler yangına ilk müdahale zamanını uzatabilecek veya k1saltabilecektir. Orman yangınları tehlike oranlamasında Ulaşılabilirlik Kriterini temsilen yer alan alt kriterler aşağıda sıralanmıştır:

- Binayı sokağa bağlayan bir araç yolu vasıtasıyla, yangın araçlarının binaya ulaşabilme kolaylı̆̆ 1 ,

- Binaya götüren ana yol ağı boyunca, yol kenarındaki vejetasyon yoğunluğu,

- Binaya götüren ana yol ağı boyunca, herhangi bir yerde karşılaşılan maksimum yol eğimi,

- Binaya götüren ana yol ağı boyunca, herhangi bir yerde karşılaşılan minimum yol genişliği,

- Araç yolunun bağlandığı ana yolun genişliği (banket yani yol kıyısı hariç),

- Araç yolunun bağlandığ́1 ana yolun üst yapısı (yüzeyi, kaplama türü-niteliği),

- Binaya götüren ana yol ağına ulaşma noktası say1s1,

- Binayı sokağa bağlayan araç yolu boyunca, yol kenarındaki vejetasyon yoğunluğu, 
- Binayı sokağa bağlayan araç yolu boyunca, herhangi bir yerde karşılaşılan maksimum yol eğimi,

- Binayı sokağa bağlayan araç yolunun genişliği (banket yani yol kıyısı hariç),

- Binayı sokağa bağlayan araç yoluna giriş-çık1ş kolaylığı,

- Binayı sokağa bağlayan araç yolu üzerindeki ulaşım köprüsünün yük taşıma sınırı,

- Binayı sokağa bağlayan araç yolu kapısı.

Alandaki Hizmetler ve Yangına İlk Müdahale Zamanı Kriteri: Bu kriter, yangın haberini alan yangın çalışanlarının araçları ve teçhizatları ile birlikte binaya ne kadar hızlı bir şekilde ulaşabileceklerini göstermektedir. Böylece yangına ilk müdahaleyi yapması beklenen en yakın yangın istasyonundan binaya gitmek için ihtiyaç duyulan zaman, orman yangınları tehlike değerlendirmelerine dâhil edilmiştir. Bu kriter kapsamında ele al1nan alt kriterler şunlardır:

- Binaya gelen ana elektrik enerjisi hatt1,

- Bina ve bina çevresindeki alanda mevcut elektrik enerjisi hatt1,

- Bina ve bina çevresindeki alanda yer üstünde elektrik enerjisi hattı mevcutsa özelliği,

- Binanın kolay bulunabilirliğini etkileyen yön ve adres levhalar1,

- Belediye itfaiye ekibinin binaya uzaklığı ve ilk müdahale zaman1,

- Orman yangın söndürme ilk müdahale ekibinin binaya uzaklığı ve ilk müdahale zamanı.

Su Mevcudiyeti Kriteri: Bu kriter, bir binanın yangından korunmasına yönelik suyun mevcudiyeti ile ilgilidir. Bir bina için iki çeşit su kaynağ mevcut olabilir. Bunlar ya binayla doğrudan bağlantılı su kaynaklarıdır veya binadan uzak kaynaklardır. Binayla doğrudan bağlantılı su kaynakları kapsamında; bina yakınındaki caddelere bulunan ve yangın söndürmek için hortum takılıp su çekilebilen yangın muslukları, sulu dereler, göletler veya binaya yeterince yakın olan ve böylece doğrudan bir su hortumu ile suyun alınabileceği sarnıçlar sayılabilir. Binadan uzak su kaynakları ise binaya suyun ancak bir su tankeriyle taşınabileceği uzaklıktaki su kaynaklarını ifade etmektedir. Böylece bu ana kriter değerlendirmeye alınan orman yangınları tehlike alt kriterleri ise şunlar olmuştur:

- Yangın musluklarının binadan uzaklığı ve gücü,
- Binaya doğrudan su alımı yapılabilecek sürekli su kaynaklarının (sulu dere, gölet, su sarnıcı vb.) binadan uzaklığı ve su sağlama kapasitesi,

- Binadan uzak diğer su alma kaynaklarına yangın aracının gidiş-dönüş zamanı.

Yukarıda belirtilen orman yangınları tehlike kriterlerinin her birine ait alt kriter puanları, arazi çalışmaları sonrasında elde edilen verilere göre belirlenmiştir.

Binaların orman yangınları tehlike oranlamasında dikkate alınan yukarıdaki kriterlere yönelik hazırlanan "bilgi toplama formu", bina ve bina sahiplerine ilişkin bilgiler yanında, her bir kritere ait bilgi toplama sorularını ve genel gözlemleri kaydetmeye yönelik bir yorum sayfasını da içermiştir. Örneğin eğer bilgi toplayıcısı herhangi bir kritere ait soruların incelenen binayı tam olarak yansitmadığını düşünüyorsa, o takdirde bu çelişkili durumun ne olduğunu ayrıntılı şekilde yorum bölümüne kaydetmiştir. Bu yorum bilgilerine dayalı olarak gerektiğinde mevcut orman yangınları tehlike kriterleri düzeltilmiş veya orman yangınları tehlike oranlamasına yeni kriterler eklenmiştir. Bu suretle uygulanan modelin gözden geçirilip düzeltilmesi ve geliştirilmesi sağlanmıştır.

\subsubsection{Değerlendirme yöntemi}

Bu çalışmada bir "orman yangınları tehlike oranlaması" modeli geliștirilmiş ve örnek alanlarda (Antalya Orman Bölge Müdürlügü sınırları dahilinde) denenmiştir. Bu model ormanlık ve makilik alanlar içerisindeki ve kenarındaki binaları, orman yang1n1 tehlikelerine göre belirli bir tehlike grubuna dâhil etmektedir. Hiyerarşik olarak yapılandırılan bu model, asil olarak elde mevcut arazi verilerine ve orman yangınları yönetimi konusunda çalışan uzman kişilerin bilgi, görüş ve deneyimlerine dayalı bir modeldir.

$\mathrm{Bu}$ araştırmada AHS tekniği kapsamındaki "ikili karşılaştırmalar" yaklaşımı yardımı ile orman yangınları yönetimi konusundaki uzmanların hükümleri ortaya konulmuş ve orman yangınları tehlike kriterlerinin ve alt kriterlerinin ağırlıkları bu uzman hükümlerine dayalı olarak belirlenmiştir. Böylece katılımcı bir yaklaşım benimsenmiş ve uygulanmıştır. Daha sonra yangın tehlike oranlamasına yönelik değerlendirmeler gerçekleştirilmesinde ve ana kriterlerin kombine edilmesinde çok kriterli çözümlemelere imkân veren "Doğrusal Kombinasyon tekniği" seçilmiş ve kullanılmıştır (Yılmaz, 2005). Sonuçta OYA alanlarındaki her bir bina tipi için yangın tehlike oranlaması (potansiyeli) ortaya konmuştur. 


\subsubsection{1. Çok kriterli yangın tehlike oranlaması}

$\mathrm{Bu}$ araştırmadaki yangın tehlike oranlamasına ilişkin değerlendirmeler, doğal olarak çok kriterli bir problem olarak görülmelidir. Bir başka ifadeyle yangın tehlike çözümlemesi çalışmalarına, birden fazla kriteri içeren bir değerlendirme veya çok kriterli karar verme problemi olarak yaklaşmak uygundur.

Buna göre çok kriterli yangın tehlike oranlaması değerlendirmelerinin matematiksel modeli, genel olarak aşağıdaki şekilde ifade edilmektedir (Mendoza, 1997):

$\mathrm{S}=\mathrm{f}\left(\mathrm{x}_{1}, \mathrm{x}_{2}, \ldots, \mathrm{x}_{\mathrm{n}}\right)$

Burada,

$\mathrm{S}=$ Yangın tehlike oranı,

$\mathrm{x}_{1}, \mathrm{x}_{2}, \ldots, \mathrm{x}_{\mathrm{n}}=$ Yangın tehlikesini etkileyen kriterler veya alt kriterlerdir.

O halde yangın tehlike oranlaması çözümlemelerindeki temel problem, $\mathrm{x}_{1}, \mathrm{x}_{2}, \ldots, \mathrm{x}_{\mathrm{n}}$ ile gösterilen farklı yangın tehlike kriterlerinin ve alt kriterlerinin hem bireysel, hem de kümülatif etkilerinin ölçülmesidir. Yangın tehlike oranlaması çözümlemeleri için bu kriterlerin ve alt kriterlerin kombine edilmesine yönelik uygun bir yaklaşımın belirlenmesi gerekmektedir.

$\mathrm{Bu}$ araştırmada çok kriterli yangın tehlike oranlaması değerlendirmesi tekniği olarak, yukarıda açıklanan matematiksel kombinasyona dayalı tekniklerden Doğrusal Kombinasyon tekniği seçilmiş ve kullanılmıştır.

Bu teknikteki yangın tehlike oranlaması yaklaş1mı matematiksel eşitlik olarak, çok kriterli yangın tehlike oranlaması değerlendirmelerine ait daha evvel sunulmuş olan yangın tehlike oranı formülünün genel bir formudur. Bu doğrusal eşitlik aşağ1daki şekilde gösterilebilir (Patrono, 1998):

$$
\mathrm{S}=\sum_{\mathrm{i}=1}^{\mathrm{n}} \mathrm{W}_{\mathrm{i}} \mathrm{X}_{\mathrm{i}}
$$

Burada,

$\mathrm{S}$ = Toplam yangın tehlike puanı,

$\mathrm{W}_{\mathrm{i}}=\mathrm{i}$ kriterinin ağırlık değeri,

$\mathrm{X}_{\mathrm{i}}=\mathrm{i}$ kriterine ait alt kriter puan1,

$\mathrm{n}=$ Kriterlerin toplam sayısıdır.

Bu çok kriterli çözümleme yaklaşımı kullanılarak, farklı kriterlerin ve alt kriterlerin kombinasyonla- rına dayalı olarak yangın tehlike oranlaması değerlendirmeleri yapılmıştır.

Yangın tehlike oranlaması çözümlemelerinde dikkate alınacak kriterler, kriter ağırlıkları, alt kriterler, alt kriter ağırlıkları ve puanları belirlendikten sonra, birden fazla sayıdaki bu kriterlerin kombinasyonunu sağlamak suretiyle çok kriterli arazi uygunluk değerlendirmeleri yapılabilecektir. Araştırmada bu amaçla, Yöntem bölümünde açıklanmış olan Doğrusal Kombinasyon tekniği kullanılmıştır.

$\mathrm{Bu}$ amaçla ilk aşamada "ağırlıklı alt kriter puanları" hesaplamaları yapılmıştır. "ağırlıklı alt kriter puanını" elde etmek üzere, her bir alt kriterin "geometrik ortalamaya dayalı alt kriter puanı" ile "geometrik ortalamaya dayalı kriter puanı" çarpılmiştır.

Ardından "çok kriterli yangın tehlike oranlaması" değerlendirmelerinin yapılacağı bir tablo oluşturulmuştur. $\mathrm{Bu}$ değerlendirme tablosunda OYA alanlarındaki her bir bina tipi itibariyle yangın tehlike potansiyelini etkileyen kriterlere ait alt kriterlerin, sahip olduğu "alt kriter puanları" ile "ağırlıklı alt kriter puanları” değerlendirme tablolarına işlenmiştir.

Sonrasında seçilen ve uygulanan yangın tehlike oranlaması tekniği olan Doğrusal Kombinasyon tekniği gereği, her bir bina tipinin sahip olduğu "alt kriter puanları" ile bu alt kriterlerin ait olduğu kriterlerin "ağırlıklı alt kriter puanları" çarpılmak suretiyle ağırlıklı puanlar elde edilmiştir. Böylece alt kriter puanları toplanabilir veya başka bir ifadeyle kombine edilebilir hale gelmiştir. Sonuçta her bir bina tipi için alt kriterlerin yukarıdaki çarpma işlemiyle elde edilen ağırlıklı puanları toplanarak her bir bina tipine yönelik "toplam yangın tehlike puanı” değerlerine ulaşılmıştır.

\subsubsection{Alt kriter puanları}

Her bir alt kriter kendi içinde elemanlara ayrılmıştır. Örneğin “topoğrafya” kriterinin bir alt kriteri olan "binanın eğim üzerindeki yeri” düz arazide, vadi tabanında (alt yamaçta), orta yamaçta, üst yamaçta birer elemanı oluşturmuştur. Böylece bu alt kriter dört eleman olarak sınıflandırılmıştır.

Sonrasında her bir alt kritere ait elemana birer puan atanmıştır. Bu puanlar verilirken, elemanların yangın tehlike oranlaması ile ilişkisine dikkat edilmiştir. Örneğin "binanın eğim üzerindeki yeri" alt kriterleri yangın tehlike oranlamasının belirlenmesine yönelik olarak ele alındığında, bu alt kritere ait elemanlardan düz arazide 1 , vadi tabanında 2 , 
orta yamaçta 3 ve üst yamaçta 4 eleman puanı verilmiştir.

Eleman puanları verilirken her ne kadar yangin tehlike oranı dikkate alınarak en olumlu durumdan en olumsuz duruma doğru olmak üzere 1, 2, 3 ve 4 şeklinde artan puanlar verilmiş olsa da, bir alt kritere ait eleman sayısının dört adetten fazla veya az olduğu diğer durumlarda bu sira gözetilmeksizin öznel bir değerlendirme ile puanlandırma yapılmıştır.

\section{Bulgular}

$\mathrm{Bu}$ bölümde ilk olarak bu teknikler kapsamında kullanılan yangın tehlike kriterlerine ve alt alt kriterlerine ait ağırlık değerlerinin ve alt kriter puanlarının belirlenmesi konusu açıklanmış ve sonrasında bunlara göre araştırma alanında gerçekleştirilen çok kriterli yangın tehlike oranlaması değerlendirmeleri ile elde edilen bulgular ortaya konmuştur.

\subsection{Kriter ve alt kriter ağırlıkları}

Yangın tehlike oranlaması çözümlemelerinde dikkate alınacak kriter ve alt kriter ağırlıkları aşağıdaki şekilde belirlenmiştir.

Yangın uzmanları tarafından ortaya konan kriter ağırlıklarının geometrik ortalama değerleri, yangın tehlike oranlaması çözümlemelerindeki "geometrik ortalamaya dayalı kriter puanı" değerlerini oluşturmuştur. Buna göre bu yangın tehlike kriterlerinden "binanın yakın çevresindeki yanıcı maddeler" kriteri 0,201 ağırlık değeri ile en önemli kriter iken, bu kriteri sırasıyla 0,175 ağırlık değeri ile "su mevcudiyeti" kriteri; 0,172 ağırlık değeri ile "binaya ulaşılabilirlik" kriteri; 0,164 ağırlık değeri ile "alandaki hizmetler ve yangına ilk müdahale zamanı" kriteri; 0,132 ağırlık değeri ile "bina inşa tarzı ve tasarımı" kriteri; 0,124 ağırlık değeri ile "yanıcı maddeler" kriteri ve 0,031 ağırlık değeri ile "topoğrafya" kriteri takip etmektedir. Bu aşamadaki ikili karşılaştırmaların ortalama Tutarlılık Oranı ise \%0,1 olarak hesaplanmıştır.

“Topoğrafya” kriteri kapsamındaki alt kriterlerden 0,398 ağırlık değeri ile "binanın tehlikeli topoğrafik özelliklere (dik yamaç, yarık, oluk, kanyon, sırt, boyun vb.) olan uzaklığı" alt kriteri, en yüksek ağırlığa sahip alt kriter olarak ortaya çıkmıştır. Bu alt kriteri sırasıyla "binadan 50 m uzaklık (yarıçap) içindeki alanın hâkim eğim yönüne ait bakı sınıfı" alt kriteri $(0,155)$, "binadan $50 \mathrm{~m}$ uzaklık (yarıçap) içindeki alanda ortalama eğim" alt kriteri $(0,126)$, “binanın eğim üzerindeki yeri” alt kriteri $(0,123)$, “binanın dik (\%30'dan daha büyük) bir eğimden olan uzaklığı" alt kriteri $(0,100)$ ve "binadan 150 m uzaklıkta bulunan tehlikeli topoğrafik özellikler" alt kriteri $(0,098)$ izlemektedir. Bu alt kriterlerin ikili karşılaştırmalarına ait ortalama Tutarlılık Oranı ise \%0,0 olarak belirlenmiştir.

"Yanıcı maddeler" alt kriterleri arasında "binadan en az 10 metre uzaklık (yarıçap) içindeki meşcerenin ara tabakası (çalılar, veya ağaçların budanmamış alt dalları)" alt kriteri 0,262 ağırlık değeri ile en önemli alt kriter olarak önemsenirken, bunu sırasıyla 0,225 ağırlık değeri ile "binadan en az $10 \mathrm{~m}$ uzaklık (yarıçap) içindeki alanda vejetasyon yoğunluğu" alt kriteri; 0,188 ağırlık değeri ile "binadan en az 10 m uzaklık (yarıçap) içindeki meșcerenin üst tabakası (ağaç türleri)" alt kriteri; 0,158 ağırlık değeri ile "binadan $50 \mathrm{~m}$ uzaklık (yarıçap) içindeki hâkim yanıcı madde tipi" alt kriteri; 0,090 ağırlık değeri ile "binadan en az 10 m uzaklık (yarıçap) içindeki meşcerenin alt tabakası (diri örtü veya toprak yüzeyi malzemesi)" alt kriteri ve 0,078 ağırlık değeri ile "bina çevresi ortam" alt kriteri takip etmektedir. Bu alt kriterlere yönelik ikili karşılaştırmalara ilişkin hükümlerin ortalama Tutarlılık Oranının ise \% 0,1 değerine sahip olduğu ortaya çıkmıştır.

"Bina inşa tarzı ve tasarımı" alt kriterlerinden "binanın çatı örtüsü malzemesi” alt kriteri 0,219 ağırlik değeri ile en önem taşıyan alt kriter iken, bu alt kriteri sırasıyla 0,166 ağırlık değeri ile "binanın duvar kaplama malzemesi” alt kriteri; 0,160 ağırlık değeri ile "bina pencerelerinin yangına dayanıklılığı" alt kriteri; 0,139 ağırlık değeri ile "binanın temeline yakın taban kısmının (bina eteği için kaplamanın) inşa ediliş tarzı" alt kriteri; 0,112 ağırlık değeri ile "bina balkonlarının malzemesi" alt kriteri; 0,077 ağırlık değeri ile "bina balkonlarının inşa ediliş tarzı" alt kriteri; 0,074 ağırlık değeri ile "binanın çatı saçakları ve çıkıntılarının inşa ediliş tarzı" ve 0,053 ağırlık değeri ile "bina bacasının yapıs1" alt kriteri izlemektedir. Bu alt kriterlerin ikili karşılaştırmalarına ait ortalama Tutarlılık Oranı ise \% 0,1 olarak saptanmıştır.

"Binanın yakın çevresindeki yanıcı maddeler" kriteri kapsamındaki alt kriterlerden 0,193 ağırlık degerine sahip "akaryakıt deposunun binadan uzaklığı” alt kriteri, en yüksek ağırlığa sahip alt kriter olarak belirlenmiştir. Bu alt kriteri sırasıyla "bina çatısındaki veya yakınındaki yanıcı maddeler (dal, vejetasyon vb.)" alt kriteri $(0,188)$, “Toprak altında veya toprak üstünde dökme gaz (LPG) tankının binadan uzaklığı” alt kriteri $(0,176)$, "bina çatısının temizliği (yaprak, çerçöp vb.)” alt kriteri $(0,100)$, "çalı-çırpı yı̆̆ılan yerin binadan uzaklığı" alt kriteri $(0,098)$, "binanın komşu binadan olan uzakl1ğ1” alt kriteri $(0,060)$, “vejetasyonun bina bacasına 
veya soba borusuna yakınlığı" alt kriteri $(0,050)$, "kulübe, baraka vb. ek yapının binadan uzaklığı" alt kriteri $(0,049)$, "yakacak odun depolama yerinin binadan uzaklığı” alt kriteri $(0,046)$ ve "çöp yakma varilinin binadan uzaklığı” alt kriteri $(0,040)$ takip etmektedir. Bu alt kriterlere ait ikili karşılaştırmaların ortalama Tutarlılık Oranı ise \%0,2 olarak hesaplanmıştır.

"Binaya ulaşılabilirlik" alt kriterlerinden "binay1 sokağa bağlayan araç yolu üzerindeki ulaşım köprüsünün yük taşıma sınırı" alt kriteri 0,122 ağırlık değeri ile en yüksek önem taşıyan alt kriter olarak benimsenmiştir. $\mathrm{Bu}$ alt kriteri sırasıyla 0,102 ağılık değeri ile "binaya götüren ana yol ağ boyunca, herhangi bir yerde karşılaşılan minimum yol genişliği”” alt kriteri; 0,097 ağırlık değeri ile "binayı sokağa bağlayan araç yoluna giriş-çıkış kolaylığı" alt kriteri; 0,088 ağırlık değeri ile "binayı sokağa bağlayan araç yolu kapısı” alt kriteri ve "binayı sokağa bağlayan bir araç yolu vasıtasıyla, yangın araçlarının binaya ulaşma kolaylığı” alt kriteri; 0,074 ağırlık değeri ile "binayı sokağa bağlayan araç yolu boyunca, yol kenarındaki vejetasyon yoğunluğu" alt kriteri ve "araç yolunun bağlandığ ana yolun genişliği (banket yani yol kıyısı hariç)" alt kriteri; 0,067 ağırlık değeri ile "binaya götüren ana yol ağı boyunca, yol kenarındaki vejetasyon yoğunluğu" alt kriteri; 0,065 ağırlık değeri ile "binayı sokağa bağlayan araç yolunun genişliği (banket yani yol kıyısı hariç)" alt kriteri; 0,062 ağırlık değeri ile "binaya götüren ana yol ağına ulaşma noktası sayısı" alt kriteri; 0,061 ağırlık değeri ile "binayı sokağa bağlayan araç yolu boyunca, herhangi bir yerde karşılaşılan maksimum yol eğimi" alt kriteri, 0,060 ağırlık değeri ile "binaya götüren ana yol ağı boyunca, herhangi bir yerde karşılaş1lan maksimum yol eğimi” alt kriteri ve 0,039 ağırlık değeri ile "araç yolunun bağlandığı ana yolun üst yapısı (yüzeyi, kaplama türü-niteliği)" alt kriteri takip etmektedir. Bu ikili karşılaştırmaların ortalama Tutarlılık oranı ise $\% 0,2$ değerine sahiptir.

"Alandaki hizmetler ve yangına ilk müdahale zamanı" alt kriterlerinden "orman yangın söndürme ilk müdahale ekibinin binaya uzaklığı ve ilk müdahale zamanı" alt kriteri 0,259 ağırlık değeri ile en önemli alt kriter olmuşken, bunu sırasıyla 0,252 ağırlık değeri ile "belediye itfaiye ekibinin binaya uzaklığ 1 ve ilk müdahale zamanı" alt kriteri; 0,170 ağırlık değeri ile "bina ve bina çevresindeki alanda yer üstünde elektrik enerjisi hattı mevcutsa özelliği”" alt kriteri; 0,140 ağırlık değeri ile "binanın kolay bulunabilirliğini etkileyen yön ve adres levhaları" alt kriteri; 0,133 ağırlık değeri ile "bina ve bina çevresindeki alanda mevcut elektrik enerjisi hattı" ve 0,046 ağırlık değeri ile "binaya gelen ana elektrik enerjisi hattı" alt kriteri izlemektedir. Bu alt kriterler kapsamındaki ikili karşılaştırmalara yönelik hükümlerin ortalama Tutarlılık Oranı ise $\% 0,2$ olarak belirlenmiştir.

"Su mevcudiyeti" kriteri kapsamındaki alt kriterlerden 0,374 ağırlık değeri ile "yangın musluklarının binadan uzaklığı ve gücü” alt kriteri, en yüksek ağırlık değerine sahip alt kriter olmuştur. $\mathrm{Bu}$ alt kriteri sırasıyla "binaya doğrudan su alımı yapılabilecek sürekli su kaynaklarının (sulu dere, gölet, su sarnıcı vb.) binadan uzaklığı ve su sağlama kapasitesi” alt kriteri $(0,361)$ ve "binadan uzak diğer su alma kaynaklarına yangın aracının gidişdönüş zamanı" alt kriteri $(0,266)$ takip etmektedir. $\mathrm{Bu}$ alt kriterin ikili karşılaştırmalarına ait ortalama Tutarlılık Oranı ise \%0,4 olarak tespit edilmiştir.

\subsection{Yangın tehlike oranlaması değerlendirmeleri}

Toplam yangın tehlike puanı değerlerine göre her bir bina tipinin yangın tehlike oranı değerlendirmesi yapılmıştır. Bu amaçla yangın tehlike oranları; "düşük yangın tehlikesi”, "orta yangın tehlikesi" ve "yüksek yangın tehlikesi" olmak üzere üç sınıfa ayrılmıştır. Bu sınıflandırmaya karşılık gelen toplam yangın tehlike puanı değerleri, Tablol'de sunulduğu şekilde kabul edilmiştir.

Tablo 1: Toplam yangın tehlike puanı değerlerine göre yangın tehlike oranları

Table 1: Fire hazard rating according to total fire hazard point

\begin{tabular}{lc}
\hline \multicolumn{1}{c}{ Yangın tehlike oranı } & $\begin{array}{c}\text { Toplam yangın tehlike } \\
\text { puanı }\end{array}$ \\
\hline Düşük yangın tehlikesi & $1,000-1,500$ \\
Orta yangın tehlikesi & $1,501-2,000$ \\
Yüksek yangın tehlikesi & $2,001-2,500$ \\
\hline
\end{tabular}

Buna göre araştırmada değerlendirmeye alınan OYA alanlarındaki her bir bina tipinin yangin tehlike oranı, en yüksek yangın tehlike oranından en düşük yangın tehlike oranına doğru Tablo 2'de sunulduğu şekilde ortaya çıkmıştır.

Tablo 2'ye göre "yüksek yangın tehlike oranına" sahip bina tipleri arasında "Orman İçi Köyde Bulunan Bina 4" 2,313 toplam yangın tehlike puanı ile en yüksek yangın tehlike oranına sahip bina tipi olarak belirlenmiştir. Bu bina tipini sırasıyla 2,192 toplam yangın tehlike puanı ile "Orman İçi Köyde Bulunan Lojman"; 2,164 toplam yangın tehlike puanı ile "Tatil Köyü 1"; 2,150 toplam yangın tehlike puanı ile "Orman İçi Köyde Bulunan Bina 6"; 2,145 toplam yangın tehlike puanı ile "Orman İçi Köyde Bulunan Bina 7”; 2,128 toplam yangın tehlike pu- 
anı ile "Orman İçi Köyde Bulunan Bina 5"; 2,118 toplam yangın tehlike puanı ile "Orman İçi Köyde Bulunan Bina 1"; 2,080 toplam yangın tehlike puanı ile "Orman İçi Köyde Bulunan Bina 3"; 2,079 toplam yangın tehlike puanı ile "Orman İçi Köyde Bulunan Bina 2" ve 2,056 toplam yangın tehlike puanı ile "Su Ürünleri Enstitüsüne Ait Atölyeler" takip etmektedir.

"Orta yangın tehlike oranına" bina tipleri arasında “Tatil Köyü 2" 1,895 toplam yangın tehlike puanı ile en yüksek yangın tehlike oranına sahip bina tipi olarak saptanmıştır. Bunu sırasıyla "Villa 4" $(1,850)$, "Su Ürünleri Enstitüsüne Ait İdare Binas1” (1,804), "Su Ürünleri Enstitüsüne Ait Lojman" $(1,785)$, "Villa 3" (1,755), "Villa 2" (1,686), "Fabrika" $(1,673)$, "Benzin İstasyonu" $(1,663)$, "Villa 1" $(1,653)$, "Okul” $(1,649)$, ve "Hastane" $(1,581)$ izlemektedir.

Buna karşın yapılan yangın tehlike oranlaması çözümlemelerinde "düşük yangın tehlike oranına" sahip bina tipi ortaya çıkmamıştır.

\subsection{Yangın tehlikesi azaltma stratejileri}

Araştırma bölgesindeki OYA alanlarında yer alan en yüksek yangın tehlike oranına sahip Orman Bölge Müdürlüğü Tek Katlı Lojman bina tipi için yangın tehlikesini azaltma stratejileri, aşağıda ele alınmaktadır.

Orman İçi Köyde Bulunan Bina 4 bina tipinin ve çevresinin genel görünümü Şekil 2'de sunulmaktadir.

$\mathrm{Bu}$ bina tipine ait yangın tehlikesi azaltma stratejileri aşağıdaki şekilde sıralanabilir:

- Binadan 10 m uzaklık (yarıçap) içerisindeki;

○ Otsu türler ve sık dallı çalılar uzaklaştırılmalıdır,

o Bina etrafına kum, çakıl vb. yanmayan materyal serilmelidir,

o Fazla nem içeren ve boyu 30 cm'den kısa yer örtücü bitkiler kullanılmalıdır,

Tablo 2: Her bir bina tipi için toplam yangın tehlike puanına göre yangın tehlike oranı

Table 2: Fire hazard rating according to total fire hazard point for each building type

\begin{tabular}{clcl}
\hline $\begin{array}{c}\text { Sira } \\
\text { numaras1 }\end{array}$ & \multicolumn{1}{c}{ Bina tipi } & $\begin{array}{c}\text { Toplam yangın } \\
\text { tehlike puanı }\end{array}$ & Yangın tehlike oranı \\
\hline 1 & Orman İçi Köy Bina 4 & 2,313 & Yüksek yangın tehlikesi \\
2 & Orman İçi Köy Lojman & 2,192 & Yüksek yangın tehlikesi \\
3 & Tatil Köyü 1 & 2,164 & Yüksek yangın tehlikesi \\
4 & Orman İçi Köy Bina 6 & 2,150 & Yüksek yangın tehlikesi \\
5 & Orman İçi Köy Bina 7 & 2,145 & Yüksek yangın tehlikesi \\
6 & Orman İçi Köy Bina 5 & 2,128 & Yüksek yangın tehlikesi \\
7 & Orman İçi Köy Bina 1 & 2,118 & Yüksek yangın tehlikesi \\
8 & Orman İçi Köy Bina 3 & 2,080 & Yüksek yangın tehlikesi \\
9 & Orman İçi Köy Bina 2 & 2,079 & Yüksek yangın tehlikesi \\
10 & Su Ür.Ens. Atölyeler & 2,056 & Yüksek yangın tehlikesi \\
11 & Tatil Köyü 2 & 1,895 & Orta yangın tehlikesi \\
12 & Villa 4 & 1,850 & Orta yangın tehlikesi \\
13 & Su Ür.Ens. İdare Binası & 1,804 & Orta yangın tehlikesi \\
14 & Su Ür.Ens. Lojman & Orta yangın tehlikesi \\
15 & Villa 3 & 1,785 & Orta yangın tehlikesi \\
16 & Villa 2 & 1,755 & Orta yangın tehlikesi \\
17 & Fabrika & 1,686 & Orta yangın tehlikesi \\
18 & Benzin İstasyonu & Orta yangın tehlikesi \\
19 & Villa 1 & 1,673 & Orta yangın tehlikesi \\
20 & Okul & 1,663 & Orta yangın tehlikesi \\
21 & Hastane & 1,653 & 1,649 \\
\hline
\end{tabular}


○ Yanıcı madde miktarı düşük ve gelişmesi yavaş çok yıllık otsu bitkiler tercih edilmelidir,

○ Kaya bahçeleri, otsu bitki adacıkları ve çiçek tarhları tesis edilebilir,

o Bina çevresindeki çalıların etrafındaki otlar oldukça kısa (yerden en fazla $10 \mathrm{~cm}$ yukarıdan) biçilmelidir,

o Çatı ve yağmur oluklarında yaprak, dal, kabuk vb. döküntülere neden olan sedir ağacı, bina çevresinden uzaklaştırılmalıdır,

o Binaya en az 5 m uzaklıktaki diğer ağaçlar uzaklaştırılmalıdır,

o Binaya 10 m'ye yakın kısımlardaki olgun haldeki geniş yapraklı ağaçlar korunabilir,

○ Boylu ağaçların kurumuş alt dalları ile yerden 3 m'ye kadar olan yeşil dalları budanmalıdir,

o Çit ve diğer donatılarda, yanıcı olmayan materyal (taş, beton vb.) kullanılmalıdır.

- Binaya 50 m uzaklık (yarıçap) içerisindeki;

o Çalı ve çalı grupları arasındaki mesafe, boylarının 3 katı olmalıdır,

o Değişik yaş ve türden bitkiler alanda bırakılabilir,

o Geniş yapraklı çalı ve ağaç türleri ile tepesi yayvanlaşmış iğne yapraklı ağaç türleri ko-
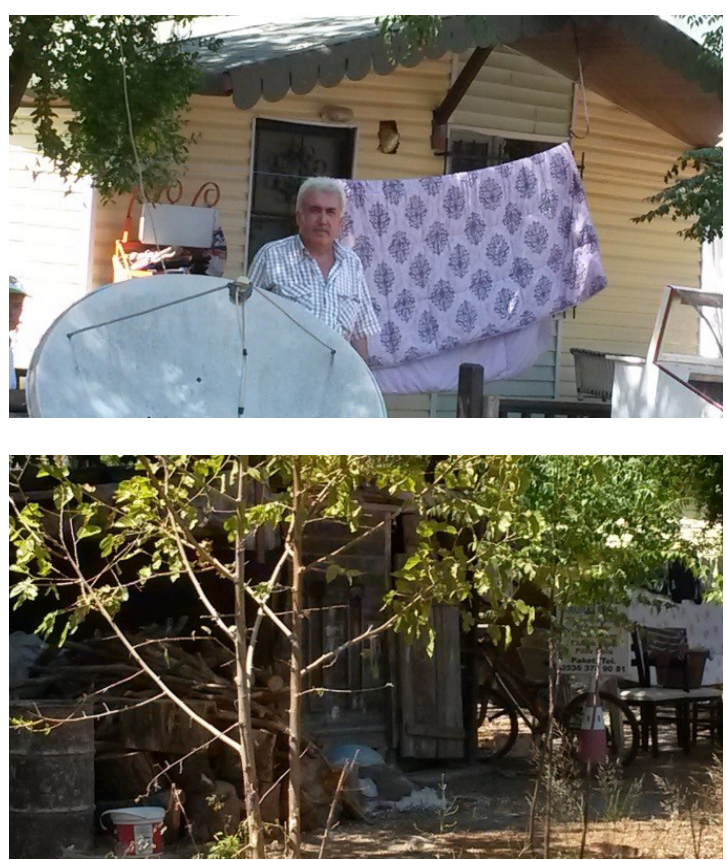

runabilir veya kullanılabilir,

○ Bitkiler sıkışık vaziyette olmamalıdır,

○ Sıkışık haldeki ağaç türlerinde aralama yapilmalidir,

o Ağaçlar yerden 2,5 m yükseklikten dallanacak şekilde ve bu türler için uygun olan zamanda kuru ve yeşil alt dalları budanmalidir.

- Binanın çatı örtüsü malzemesi kiremitten betona dönüştürülmelidir.

- Binanın çatı saçakları ve çıkıntıları kapatılmalidir.

- Bina pencerelerinde ısıtılmış (temperli) cam kullanılmalıdır.

- Yakacak odun depolama yeri bina bitişiğinden alınarak, binadan $5 \mathrm{~m}$ daha fazla uzakl1ğa taşınmalıdır.

- Bina çatısının üzerine doğru sarkan ince ve kalın ağaç dalları uzaklaştırılmalıdır.

- Bina çatısına dağılmış ve serpilmiş halde bulunan ve derinliği $1 \mathrm{~cm}$ 'den daha az olan iğne yapraklar ve geniş yapraklar, çatıdan temizlenmelidir.

- Bina bacasina 5 m'den daha az uzaklıkta bulunan vejetasyon uzaklaştırılmalıdır.

- Binaya götüren ana yol ağı boyunca bulunan yol kenarındaki vejetasyon, minimum miktar
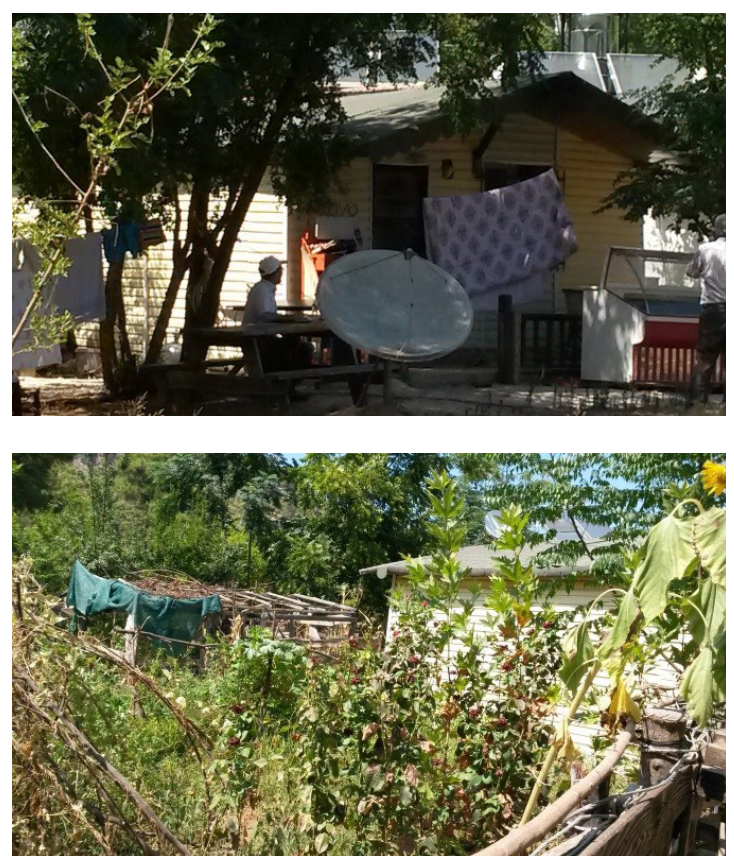

Şekil 2: Orman içi köyde bulunan bina 4 bina tipinin ve çevresinin görünümü.

Figure 2: Building 4 type and its surrounding. 
ve boyuta dönüştürülmelidir.

- Binayı sokağa bağlayan araç yolu boyunca yol kenarındaki 4,5 m'den daha aşağıda olan ve yolu kapatan ağaç dalları uzaklaştırılmalidir.

- Tümüyle yer üstündeki (bakımsız ve iyi durumda olmayan) ana elektrik enerjisi hatt1, tümüyle yer altına alınmalı ve kolayca anlaşılır şekilde işaretlenmelidir.

- Tümüyle yer üstünde (bakımsız ve iyi durumda olmayan) ve ağaçların düşme alanında (yani en azından bitişik ormandaki ortalama bir ağaç boyu uzaklıkta) ve yangın araçlarının binaya ulaşmalarını engelleyebilecek durumda olan bina ve bina çevresi alandaki mevcut elektrik enerjisi hattı, tümüyle yer altına alınmalı ve kolayca anlaşılır şekilde işaretlenmelidir.

- Bina çevresine hortum takılarak doğrudan su çekilebilecek bir yangın musluğu konmalıdır.

\section{Tartışma ve Sonuç}

Özellikle Batı Avrupa ülkelerinde, Kuzey Amerika'da ve Avustralya'da OYA alanlarına verilen önem giderek artmaktadır. Zira bu tür OYA yangınlarında evler ve diğer yapılar tahrip olmakta, insanlar sakat kalmakta veya ölmekte ve sorumlu kuruluşların finansal kapasitesi sıkıntıya girmektedir. Ülkemizin de içinde bulunduğu Akdeniz ortamında OYA kavramı, büyük orman yangınlarıyla karşılıklı ilişkisinden dolayı, özel bir öneme sahiptir. Büyük orman yangınlarının etkin olarak yönetimi, OYA alanlarının mevcudiyetini dikkate almak suretiyle gerçekleştirilebilir.

$\mathrm{Bu}$ araştırmada OYA alanı içindeki parsellerin tehlike oranlamasına yönelik özel olarak geliştirilen bir "Orman Yangınları Tehlike Oranlaması Modeli” kullanılarak veriler değerlendirilmiştir. Bu model yaklaşımı yeni yerleşim yerlerinde, orman yangınları oluşumunda ve yoğunluğunda hangi kriterlerin ne kadar etkili olduğunu göstermesi açısından önemlidir. Bu metotlar yerel, bölgesel ve ulusal düzeylerde orman yangınlarına karşı yerleşim alanlarını daha iyi değerlendirme, önceliklendirme ve orman yangını riskini ve tehlikesini azaltma yönünde Orman Genel Müdürlüğüne imkân vermektedir. Böylece orman yangını riskinin ve tehlikesinin düşürülmesi, bir orman yangını yönetiminin en yüksek önceliği olan güvenlik dikkate alındığında, kamu ve yangınla mücadele ekiplerine yönelik riski düşürecektir. Ayrıca yüksek riskli ve tehlikeli alanların belirlenmesi; yerleşim yeri felaketleri olasılığını azaltma ve risk azaltma çalışmalarını daha öncelikli alanlara yöneltilmesini sağlayabilecektir.

OYA alanlarında ikamet eden bina sahiplerinin özellikle bilmesi gereken konular ve olası eylemler listesi aşağıda verilmiştir:

1. Vejetasyon kesmeler, silvikültürel aralamalar, hayvan otlatmalar, kimyasal mücadeleler, denetimli yakmalar gibi yanıcı madde azaltma işlemleri uygulama.

2. Değerli alanlarda, yüksek tutuşabilir özellikteki yanıcı maddeleri ortadan kaldırmayı veya tehlikeli yanıcı maddelerin sürekliliğini kırmayı amaçlayan yanıcı madde izolasyon (tecrit) stratejileri.

3. Alanda mevcut kolay tutuşabilir yanıcı maddelerin, daha az tutuşabilir örtü tipiyle değiştirmesini içeren yanıcı madde dönüşüm stratejileri.

4. OYA alanı çevresinde ve OYA içindeki binalar arasında bir "Savunulabilir Yer (Bina Tutuşabilirlik Zonu)" oluşturulması, korunması ve sürdürülebilir kılınması.

5. OYA alanlarındaki binaların yangına dayanıklılığını arttırma.

6. Yakacak odun istifleri, bahçe mobilyası ve aletleri ile odundan yapılmış depo kulübesi gibi bina dışındaki kolay tutuşabilir malzemelerin uzaklaştırılması.

\section{Yapısal (strüktürel) değerlendirmeler.}

8. Binalara doğru görülebilir ikametgâh yön işaretleri, geçit veren yollar veya erişilebilir güzergâhlar tesis etmek ve korumak ihtiyac1.

OYA alanlarındaki orman yangını tehlikesini azaltmaya yönelik politika önlemleri ise aşağıdaki şekilde belirtilmiştir;

1. OYA sakinlerinin mülkiyetlerindeki vejetasyonu azaltmaları yönünde teşvik edilmelidir,

2. OYA sakinlerini, binaları çevresinde iyi bir "Savunulabilir Alan" oluşturmayı benimsemeleri yönünde cesaretlendirilmelidir,

3. Yangın istasyonlarına yakınlık konusunun önemini vurgulamak için daha fazla araştırma yapılmalı ve yangın istasyonları bu araştırma sonuçlarına göre konuşlandırılmalıdır.

4. Yüksek eğimlerde (\%25'den daha büyük) inşaata sınırlı şekilde izin verilmeli ve eğer yapı inşaat kısıtlaması uygulanamıyorsa, bir binaya izin verilmeden önce böyle taşınmazlarda vejetasyonun temizlenmesi sağlanmalıdır, 
5. Parsel alanlarına doğru giden yol oranı arttırılmalı ve stratejik yerlerde yol yapılmalıdır,

6. Veri kaynağı olması açısından, faydalı bir orman yangınları tehlike değerlendirilmesine yönelik yüksek çözünürlüklü uzaktan algılama verilerine ve diğer mekânsal verilere ihtiyaç duyulmaktadır,

7. OYA alanlarındaki bina sahiplerinin binanın yakın çevresindeki yanıcı maddelere yönelik uygun peyzaj düzenlemelerini yerine getirmeleri zorunluluğu getirilmelidir,

8. OYA alanlarındaki bina inşaatlarına yönelik alınacak inşaat ruhsatları ve izinlerinde, binalar arasındaki uygun mesafe, binalarda yanmaya dayanıklı bina malzemelerinin kullanımı ve yangına karşı yapı inşa tarzı ve tasarımı ilkelerine uygunluğun zorunlu tutulması gerekmektedir,

9. OYA alanlarındaki binalara yönelik yangın sigortası uygulamasının zorunlu tutulması gerekmektedir,

10. Yangın öncesi çalışmalara ve planlamalara esas olan il orman yangınlariyla mücadele komisyon kararlarında ve yangın eylem planlarında, OYA alanlarındaki bina ve bina çevrelerindeki orman yangınları tehlikesini azaltmak için hangi önlemlerin alınacağının da belirtilmesine ihtiyaç bulunmaktadir.

OYA sorununun üstesinden gelme yönünde en yüksek önceliğe sahip olan konu, ilgi gruplarıyla iletişime ve işbirliğine geçmektir. OYA alanında yaşayan toplum üyelerinin eğitilmesi, yangına karş1 güvenli sonuçlara ulaştırabilecektir. Bu amaçla bina sahiplerinin orman yangınlarına yönelik görüşlerini incelemek ve bu yangınların etkilerini azaltmaya yönelik kişilerin yaklaşımlarını değerlendirmek üzere, bir anket çalışması gerçekleştirilebilir. Aynı zamanda OYA alanlarında tehlike durumunu değerlendirmek üzere sörveyler ve farklı eğitim yaklaşımları kullanılabilir. Ardından hangi eğitim işleminin, bina sahiplerinin davranışında en büyük değişiklikle sonuçlandığı ortaya konulabilir. Böylesi bir araştırmanın kısa dönemli amaçları (1) bina sahipleri tarafindan OYA konularını anlama düzeylerini belirlemek, (2) bina sahiplerinin ve mülkiyet özelliklerinin incelenmesi suretiyle, eğitimden önce özel mülkiyetin tehlike düzeyini ortaya koymak, (3) bina sahiplerinin orman yangınına karşı en etkili davranış değişikliğine neden olan eğitim yaklaşımını belirlemek üzere, özel mülkiyet sahipleri üzerinde farklı eğitim yaklaşımlarını sınamak olarak sıralanabilir. Araştırma alanı yakınında bulunan Uluslararası Ormancılık Eğitim Merkezi Müdürlüğü, OYA kapsamında kamunun eğitilmesi görevini, ilk aşamada Antalya ili için üstlenmelidir. Bu kapsamda uygun OYA uygulamalarının pratik eğitimi yanında, uygun OYA alanlarını sergileyen demonstrasyon alanları da oluşturulmalıdır. Ayrıca bu Merkez, tüm OYA ilgi grupları arasında işbirliği ve uyumun sağlanacağ1 bir merkez olma özelliğine de kavuşmalıdır.

\section{Teşekkür}

Bu makale, 2014-2017 yıllarında T.C. Orman ve Su İşleri Bakanlığı, Batı Akdeniz Ormancılık Araştırma Enstitüsü Müdürlüğünce aynı başlıkla gerçekleştirilen araştırma sonucunda hazırlanan ve OGM Araştırma İhtisas Grupları Toplantısında yayınlanması yönünde karar verilen 19.5314/2014-20152017 numaralı Proje Sonuç Raporunun (Yılmaz ve ark., 2017) özetidir.

\section{Kaynaklar}

Eufirelab, 2004. Towards Method for Investigating on Wildland Fire Causes. In: Bonora, L., Conese, C., Lampin, C., Martin, P., Martinez, J., Molina, D., Salas, J. (Eds.), Eufirelab: Euromediterranean Wildland Fire Laboratory, a "Wall-less" Laboratory for Wildland Fire Sciences and Technologies in the Euro-Mediterranean region, Deliverable D-05-02, 43 pages.

Farmer, D. A., 1998. Larimer County Wildfire Mitigation Plan, 1998: U.S. Department of Agriculture, Forest Service, Colorado State Forest Service, Fort Collins District, September 1995, Revised April 1998, Colorado, USA, pp: 44.

Gençol, M., 2009. Orman Yangınlarıyla Mücadelede Yerleşim Alanlarının Güvenliği, Yangın Emniyet Yol ve Şeritlerine Yeni Bir Yaklaşım. T.C. Çevre ve Orman Bakanlığı, Orman Genel Müdürlüğ̈̈, I. Orman Yangınları İle Mücadele Sempozyumu, 07-10 Ocak 2009, Tebliğler Kitab1, s. 112-116, Antalya.

Hay, C. M., 2000. A Wildfire Hazard Rating Model for Structures/Parcels in the Wildland/Urban Interface, In: Proceedings of the 13th Conference on Fire and Forest Meteorology, 27-31 October 1996, Lorne, Victoria, Australia.

Johnson, M., Korte, J., Hay, C. M., 1993. A Wildfire Hazard Identification and Mitigation System (WHIMS) for Boulder County, Colorado, In: Proceeding of the 1993 GIS in the Rockies Conference, ASPRS, Golden, CO, USA.

Küçükaydın, A., 2009. Orman Yangınlarının Önlenmesine Dair Mevcut Düzenlemelerdeki Hukuki Sorumluluklar, Alınması Gereken Tedbirler. T.C. Çevre ve Orman Bakanlı̆̆ 1 , Orman Genel Müdürlüğ̈̈, I. Orman Yangınları İle Mücadele Sempozyumu, 07-10 Ocak 2009, Tebliğler Kitabı, s. 131-137, Antalya.

Lampin-Maillet, C., 2008. 2007, Summer Fires in the European Mediterranean-The cases of Greece, İtaly and 
Spain. Mediterranean yearbook, European Institute of the Mediterranean, Med. 2008, Economy and TerritorySustainable Development, pp: 243-247.

McCaffrey, S. M., 2002. For Want of Defensible Space a Forest is Lost: Homeowners and the Wildfire Hazard and Mitigation in the Residential Wildland Intermix at Incline Village, Nevada, University of California, Wildland Resource Science, Berkeley, USA, pp: 300.

Mendoza, G. A., 1997. GIS-Based Multicriteria Approaches to Land Use Suitability Assessment and Allocation. Seventh Symposium on Systems Analysis in Forest Resources (May 28-31, Treverse City, Michigan, USA), United States Department of Agriculture (USDA), Forest Service, North Central Research Station, General Technical Report NC-205, USA, pp: 89-94.

Neyişçi T., 2009. Ezber Bozmak ya da Yangın Aforizmaları, Orman ve Av Dergisi, Mayıs-Haziran Sayıs1, Say1: 3, Cilt: 85, s. 3-6, ISSN: 1302-040X.

Patrono, A., 1998. Multi-Criteria Analysis and Geographic Information Systems: Analysis of Natural Areas and Ecological Distributions, Multicriteria Analysis for Land-Use Management, Edited by Euro Beinat and Peter Nijkamp, Kluwer Academic Publishers, Environment and Management-Volume: 9, ISBN: 0-7923-5198-3, AA Dordrecht, The Netherlands, pp: 271-292.

Schmoldt, D. L., Peterson, D. L., Smith, R. L., 1994. The
Analytic Hierarchy Process and Participatory Decision Making. Proceedings from Decision Support 2001, Volume: 1, 17th Annual Geographic Information Seminar and the Resource Technology 94 Symposium, Toronto, Ontario, September 12-16, 1994.

Slack, P., 2000: Firewise Construction, Design and Materials. Colorado State Forest Service, USA, pp: 37.

Tele, W. C., Weatherford, 2000. The Wildland/Urban Interface Fire Problem. Report to the Council of Western State Foresters, California, CA 95672, USA, pp: 97.

Y1lmaz, E., 2005. Bir Arazi Kullanım Planlaması Modeli: Cehennemdere Vadisi Örneği. T.C. Çevre ve Orman Bakanlığı, Doğu Akdeniz Ormancılık Araştırma Müdürlüğü, Çevre ve Orman Bakanlığı Yayın No: 253, DOA Yayın No: 37, Çeșitli Yayın No: 3, 131 s., Tarsus.

Yılmaz, E., Koçak, Z., Coşgun, U., Ay, Z., Bilgin, F. ve İ. Şafak, 2012. Orman Yangınları Yönetiminin Bütünleyici Karmaşıklık Yöntemiyle Değerlendirilmesi. T.C. Orman ve Su İşleri Bakanlığı, Doğu Akdeniz Ormanc1lık Araştırma Enstitüsü Müdürlüğü, DOA Yayın No: 67, Teknik Bülten No: 41, 124 s., Tarsus.

Y1lmaz, E., Kayacan, A., Güler, K. H., 2017. Orman İçi ve Kenarı Yerleșimlerde Orman Yangınları Tehlike Oranlamas1 Modeli: Antalya Orman Bölge Müdürlüğü Örneği. T.C. Orman ve Su İşleri Bakanlığ 1 , Batı Akdeniz Ormanc1lık Araştırma Enstitüsü Müdürlüğü, Sonuçlanan Proje Sonuç Raporu, 285 s., Antalya. 